\title{
The Digestate: A Nutrient Source for the Alternative Biomass for Anaerobic Digestion
}

\author{
Ján Gaduš ${ }^{1)}$ and Natalia Głowacka ${ }^{1,2)}$ \\ ${ }^{1)}$ Department of Regional Bioenergy, FESRD, SUA in Nitra, Nitra, Slovakia, \\ e-mail: jan.gadus@uniag.sk/natalia_glowacka@interia.eu \\ 2) Environmental Institute, s.r.o., Koš, Slovakia, e-mail: natalia_glowacka@interia.eu
}

\begin{abstract}
Construction of new biogas plant stations in Europe is a steadily growing trend, that is the reason why there is a need to find a proper alternative source of energy, which can replace traditional crops used for generation of energy. Microalgae represent a high potential of energy. When comparing microalgae with traditional crops, we can point out their high potential (oil content). During the production of biogas from traditional input materials, it is still a great potential of resulting organic waste fermentation water (digestate), which can be used in a closed cycle in the intensive year-round cultivation of microalgae. Using the by-product (digestate) generated during the process of anaerobic digestion we can create a system for the cultivation of microalgae, which will in turn be used as a raw material for the biogas plant. Thanks to such application, the biogas plant can be more 'selfsufficient'. This new innovative process can provide a prerequisite scale for increasing commercial use of bioenergy from microalgae. However, there is a need to find a reasonable way to produce the algae biomass to meet all ecological and economic requirements.
\end{abstract}

Keywords - digestate, microalgae, anaerobic digestion, circular economy.

\section{INTRODUCTION}

Biogas plant produces during the process of anaerobic digestion the digestate, which is biologically stable and partially hygienic organic product [1]. The digestate is the organic element which contains high content of mineral ingredients, thanks to it; digestate is commonly used as an organic fertiliser for crops. However, the usage of digestate as fertiliser requires its storage in tanks for 6 months, which can lead to additional financial costs and storage problems. Recovery of the liquid digestate can become a method to produce biomass which can be in turn used as a raw material for biogas production. The digestate can directly be used as a source of nutrients for algae cultivation. Cultivation of the microalgae can be the effective way how to use the digestate for environmental (hygienisation of digestate) and economical benefits. This application could provide the opportunity for the direct usage of the digestate, without need of its storage.

\section{DIGESTATE}

\section{A. Characteristics of Digestate}

Digestate is an important by-product which consists of liquid (80-90\%) and solid (10-20\%) fractions [2]. The main features of the digestate are contents of nitrogen $(\mathrm{N})$, phosphorus (P) and minerals that is why digestate is usually utilised as agricultural fertiliser [3]. The chemical composition of the digestate samples is presented in Table I.

TABLE I.

COMPOSITION OF SELECTED DIGESTATES [4]

\begin{tabular}{|c|c|c|c|}
\hline Parameter & $\begin{array}{c}\text { Digestate } \\
\text { A }\end{array}$ & $\begin{array}{c}\text { Digestate } \\
\text { B }\end{array}$ & $\begin{array}{c}\text { Digestate } \\
\mathrm{C}\end{array}$ \\
\hline DM (g/L) & $94 \pm 5$ & $28 \pm 3$ & $<0.1$ \\
\hline ODM (g/L) & $65 \pm 2$ & $15 \pm 3$ & $<0.1$ \\
\hline COD (gCOD/L) & $74 \pm 8$ & $18 \pm 4$ & $<0.1$ \\
\hline Total Nitrogen (mgN/L) & $5218 \pm 314$ & $2750 \pm 112$ & $37 \pm 6$ \\
\hline VFA (acetic acid, mg/L) & $<100$ & $<100$ & $<20$ \\
\hline Ammonia (mgN/L) & $2949 \pm 197$ & $1450 \pm 65$ & $35 \pm 5$ \\
\hline Total Phosphorus (mgP/L) & $4870 \pm 390$ & $480 \pm 44$ & $6.5 \pm 0.9$ \\
\hline Orthophosphate (mgP/L) & $85 \pm 25$ & $30.5 \pm 5.2$ & $6.2 \pm 0.8$ \\
\hline $\mathrm{CaCO}_{3}(\mathrm{mg} / \mathrm{L})$ & $13.02 \pm 750$ & $3780 \pm 227$ & $406 \pm 54$ \\
\hline pH & $8.2 \pm 0.1$ & $7.9 \pm 0.2$ & $7.6 \pm 0.5$ \\
\hline Conductivity (mS/cm) & $26 \pm 3$ & $5.4 \pm 0.9$ & $0.4 \pm 0.1$ \\
\hline
\end{tabular}

It was noticed that the liquid digestate contains nitrogen (total nitrogen (TN): 139-3456 mg/l) and phosphorus (total phosphorus (TP): 7-381 mg/l). In the digestate there is also the ammonia nitrogen (ammonium nitrogen) which is the main element of total nitrogen $(65-98 \%)$ [5].

\section{B. Utilisation of Digestate by Microalgae}

Microalgae can be a perfect solution to utilize the digestate and convert it into energy. One of the denouements to utilize the by-products from the biogas plant is the production and cultivation of green algae, which after growing based on the by-products from a biogas plant, can be in turn used as a feedstock in the process of the anaerobic digestion. Such reuse of technological by-products forms an excellent opportunity to integrate the energy producing/consuming technologies by processing by-products and remaining waste. The approach of the cultivation of microalgal biomass with the use of by-products (digestate, $\mathrm{CO}_{2}$, heat) from the biogas plant is presented in Fig. 1.

The first experiments performed with the use of the digestate for the algae cultivation were carried out by Golueke and Oswald [6]. Uggetti [7] has investigated that 
the usage of the digestate liquid phase can be a perfect source of carbon which can have a positive effect on the increase of algal growth. The productivity of final density of biomass of microalgae which were cultivated in a liquid digestate usually ranges between: $0.03-0.67 \mathrm{~g} / \mathrm{l} / \mathrm{d}$ and 0.4 $4.8 \mathrm{~g} / \mathrm{l}$ [5]. The digestate contains phosphorus (phosphate) which is important for the growth of microalgae; it enables to run various cellular processes (energy transfer) as well as the synthesis of DNA [8]. The digestate also contains some other microelements (e.g. zinc, nickel, cobalt, iron, molybdenum, boron) and macroelements (e.g. potassium, sulphur, manganese) [9].

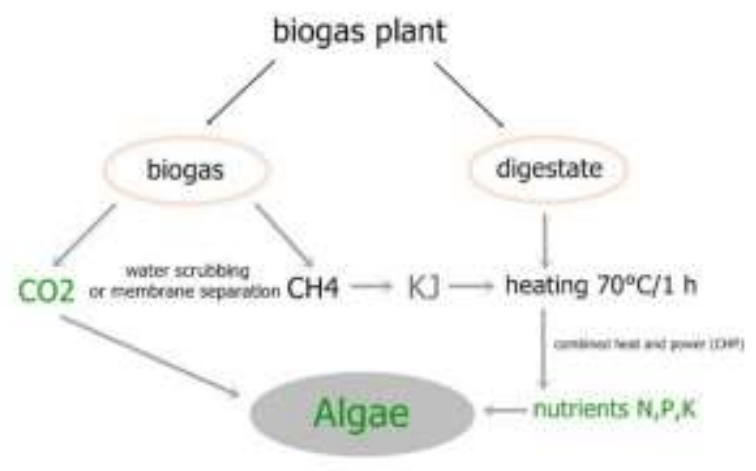

Fig. 1. The process of the algae cultivation using by-products from biogas plant (author).

The problematic issue involved in the usage of the digestate is its biological (bacterial) contamination, microorganisms (grazers) present in the digestate which can cause damage in microalgal cultivation system (some rotifers available in digestate can feed on algae). The presence of some microorganisms is inevitable and should be controlled; otherwise the contamination (zooplankton) can inhibit the focused cultivation of the microalgae. The presence of bacteria is unavoidable and should be somehow controlled, furthermore there is also an issue with another contamination such as other types of algae, viruses, zooplankton (rotifers), which can inhibit the cultivation and phases of growth of the target microalgae. The digestate [10] from the untreated biomass (from the period of February) is free from pathogens due to lower temperature. However the biological contamination can be partially removed by filtration (can remove large microorganisms) or chemical methods (which can inhibit zooplankton) [11]. Additionally, the sterilisation process can also notably reduce the content of Escherichia coli in the digestate [10]. Alternatively, one of the ways how to reduce the contamination is the control of environmental (e.g. light) or operational (nutrient supply, $\mathrm{pH}$ ) factors [12].

\section{MATERIAL AND METHODS}

The genus of microalgae Chlorella sorokiniana was selected for this study (due to not complicated cultivation strategy). The cultures of the microalgae were cultivated in an open one-segment raceway pond system (manufactured by AQUAFLOT s.r.o.), made from plastic, with the working volume of $200 \mathrm{~L}$ (as shown in Fig. 2), installed in a greenhouse. The microalgae were kept in non-sterile conditions. The optimum temperature was maintained around $35^{\circ} \mathrm{C}$. The proper $\mathrm{pH}$ level was kept between 7.0 and 7.3. No artificial light was used. The microalgae were cultivated during the period from 25 July to 5 September 2017.

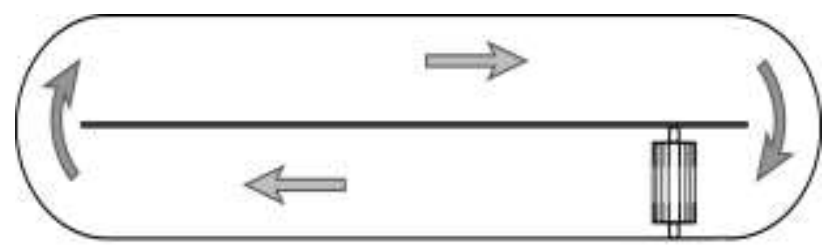

Fig. 2. Scheme of open one-segment raceway pond system 200 L volume (author).

The highest concentration of the algal biomass cultivated in an open pond with the use of the digestate was $1.22 \%$ of dry matter (77.14\% of organic dry matter). The increase of biomass is illustrated in Fig. 3.

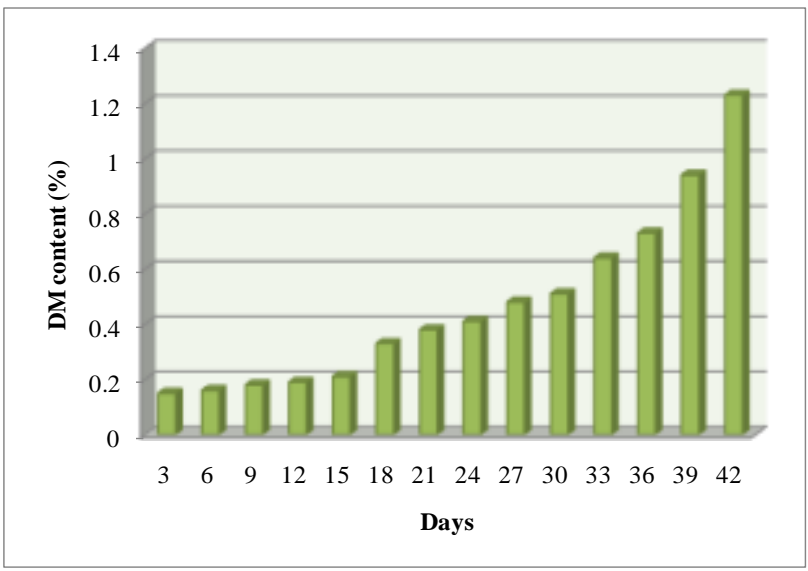

Fig. 3. The content of dry matter (\%) in samples of Chlorella sorokiniana cultivated with the use of digestate (author).

It is necessary to evaluate the composition of the digestate, which will be used for the microalgae cultivation (as shown in Table II). The technology with the use of fermentation water can also require thermal processing to reduce the amount of pathogens and microorganisms that may infect the purity of the algal suspension (Rotifers, grazers).

TABLE II.

Composition of Digestate Used for Algae Cultivation (AUTHOR)

\begin{tabular}{|c|c|}
\hline Digestate & Value / Dilution \\
\hline $\operatorname{COD}(\mathrm{mg} / \mathrm{l})$ & $8000 / 1: 20$ \\
\hline $\mathrm{NH}_{4}(\mathrm{mg} / \mathrm{l})$ & $<50 / 1: 20$ \\
\hline $\mathrm{SO}_{4}{ }^{2-}(\mathrm{mg} / \mathrm{l})$ & $397 / 1: 2$ \\
\hline NTOT (mg/l) & $465 / 1: 20$ \\
\hline Temperature $\left({ }^{\circ} \mathrm{C}\right)$ & 20 \\
\hline pH: & 7.26 \\
\hline DM: & 0.12 \\
\hline ODM:\% & 0.45 \\
\hline ODM\%DM: & 70.00 \\
\hline
\end{tabular}




\section{PROCESSING OF BIOMASS}

The microalgae biomass ( $3 \mathrm{~L})$, concentration of DM $0.85 \%$, was processed during the comparative test of biogas yield in the workplace of the Department of Regional Bioenergy in Kolín̆any. For our experiment we used the experimental fermenter for batch tests. The fermenter was constructed from the following parts: stainless steel tank (100 L of net volume), electric water heating, digital temperature control, electric low-speed mixer (12 cycles of mixing per day from 20-30 minutes). The value of the achieved biogas was recorded every hour.

Processed outputs of the monitored parameters are given in the table and graphs. The values of the monitored parameters and chemical composition of microalgae and inoculum are presented separately in Table III. The cumulative production of the biogas is presented in Fig. 4. The course of methane, carbon dioxide and hydrogen sulphide content in the biogas is showed in Fig. 5.

TABLE III.

THE VALUES OF MONITORED PARAMETERS AND CHEMICAL COMPOSITION OF THE BIOMASS (MICROALGAE INOCULUM)

\begin{tabular}{|c|c|c|c|}
\hline Parameter & Unit & $\begin{array}{c}\text { Input substrate } \\
\text { microalgae }\end{array}$ & $\begin{array}{c}\text { Input substrate } \\
\text { inoculum }\end{array}$ \\
\hline Temperature & ${ }^{\circ} \mathrm{C}$ & 20 & 20 \\
\hline DM & $\%$ & 0.85 & 1.06 \\
\hline ODM & $\% \mathrm{DM}$ & 73.33 & 76.09 \\
\hline $\mathbf{C O D}$ & $\mathrm{mg} / 1$ & 10000 & 9000 \\
\hline $\mathbf{N H}_{4}{ }^{+}$ & $\mathrm{mg} / \mathrm{l}$ & 50 & 220 \\
\hline
\end{tabular}

$\mathrm{NH}_{4}{ }^{+}-$ammonium ions

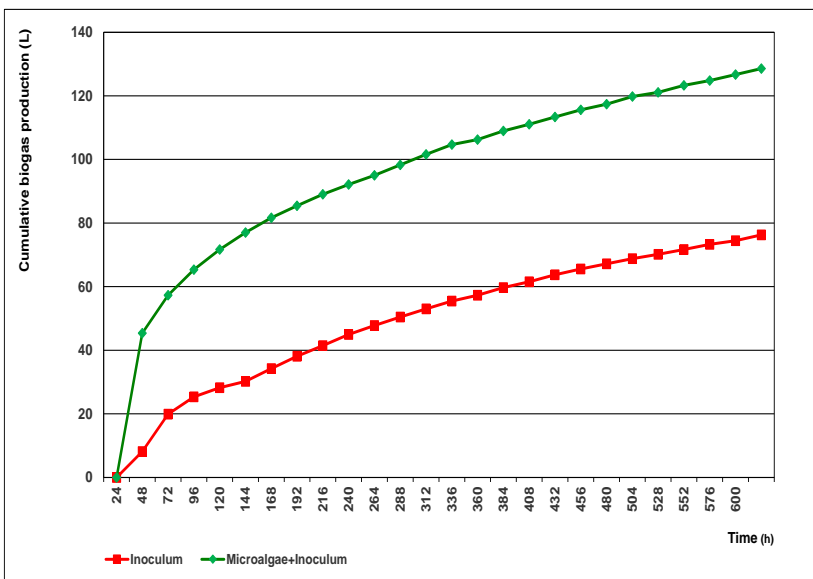

Fig. 4. The cumulative production of biogas from Chlorella sorokiniana with inoculumand and the cumulative production of biogas from inoculum (author).

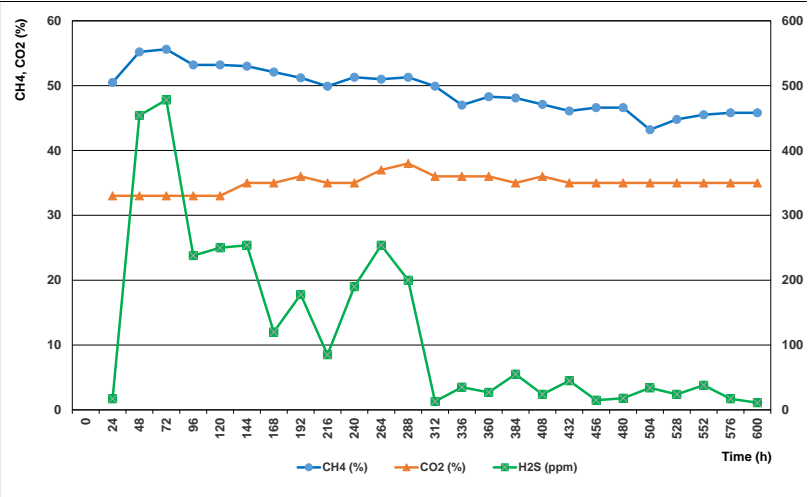

Fig. 5. The course of methane, carbon dioxide and hydrogen sulphide content in the biogas (author).

\section{RESULTS}

The experiment has confirmed that the biomass of the microalgae is a proper raw material to be used in the process of the anaerobic digestion (wet fermentation). The substrate (dry algal biomass + inoculum) has produced in total $128.57 \mathrm{~L}$ of biogas in the period of 600 hours, where the addition to the production of the biogas of inoculum separately $(97 \mathrm{~L})$ was $76.27 \mathrm{~L}$. We achieved the acceptable values of methane in the produced biogas (49.29 \% by its volume) and low values of hydrogen sulphide (122.96 ppm). The produced biogas would require the minimal desulphurisation (below $100 \mathrm{ppm}$ ). During the experiment (600 hours) in the experimental fermenter, we achieved the total biogas production of 128.57 L, which means the daily production of $5.14 \mathrm{~L} /$ per day. The average $\mathrm{pH}$ value in the fermenter was 6.44 and the average temperature was $39.6{ }^{\circ} \mathrm{C}$ during the whole time of the experiment. The conversion of the biomass to the value of dry matter by the detection of the dry matter content (DM matter \%) of concentrated microalgae (which was $0.85 \%$ ) in the fermenter was as follows:

DM dose $=0.0255 \mathrm{~kg}$ of DM of substrate

ODM dose $=0.0187 \mathrm{~kg}$ of ODM of substrate

The average overall production of the biogas (BP) on the unit of dry matter of the substrate was as follows:

$\mathrm{BP}$ production $=2.051 \mathrm{~m}^{3} / \mathrm{kg} \mathrm{DM}$

To compare the results with other experiments, we can see that the results obtained from the same experiment but with the use of $3 \mathrm{~kg}$ of maize silage show that the production of the biogas in conversion to dry matter of the input material was $0.7138 \mathrm{~m}^{3} / \mathrm{kg} \mathrm{DM}$ which was almost 3 times lower than the production of the biogas from microalgae Chlorella sorokiniana.

\section{CONCLUSION}

After the conducted experiment, we can conclude that the microalgal biomass is the proper input material for biogas production; it generates the biogas with high methane content and low content of hydrogen sulphide. 
The digestate can be the real source of nutrients for the year-round cultivation of the microalgae, the usage of the digestate as fertiliser for the algal growth can reduce the environmental threats and financial costs of cultivation system, however, the area of the digestate processing is still evolving. When getting ready the application for cultivation of the microalgae we should remember, that the selection of proper genus of the microalgae, suitable cultivation technology, and proper culture conditions have a big influence on the production costs. Our research results have shown that the microalgae Chlorella sorokiniana is predicted to be a promising raw material and has a huge prospect in the future of bioenergy. However, the limitations which can be faced in the development of the algae biomass production technology still need to be taken into consideration.

\section{ACKNOWLEDGMENT}

This work was supported by the Research Center AgroBioTech built in accordance with the project Building Research Centre "AgroBioTech" ITMS 26220220180.

\section{REFERENCES}

[1] F. Tambone, P. Genevini, G. D'Imporzano, and F. Adani, "Assessing amendment properties of digestate by studying the organic matter composition and the degree of biological stability during the anaerobic digestion of the organic fraction of MSW," Bioresource Technology, vol. 100 (12), pp. 3140-3142, 2009. https://doi.org/10.1016/j.biortech.2009.02.012

[2] W. Fuchs and B. Drosg, "Assessment of the state of the art of technologies for the processing of digestate residue from anaerobic digesters," Water science and technology, vol. 67 (9), pp. 19841993, 2013.

https://doi.org/10.2166/wst.2013.075
[3] D. Veronesi, A. Ida, G. D’Imporzano, and F. Adani, "Microalgae Cultivation: Nutrient Recovery from Digestate for Producing Algae Biomass," Chemical Engineering Transactions, vol. 43, ISBN 97888-95608-34-1; ISSN 2283-9216, 2015.

[4] L. Zuliani, N. Frison, A. Jelic, F. Fatone, D. Bolzonella, and M. Ballottari, "Microalgae Cultivation on Anaerobic Digestate of Municipal Wastewater, Sewage Sludge and Agro-Waste," International Journal of Molecular Sciences, vol. 10, 17 p., 2016.

[5] A. Xia and J. D. Murphy, "Microalgal Cultivation in Treating Liquid Digestate from Biogas Systems," Trends in Biotechnology, vol. 34 (4), pp. 264-275, 2016. https://doi.org/10.1016/j.tibtech.2015.12.010

[6] C. G. Golueke and W. J. Oswald, "Biological Conversion of Light Energy to the Chemical Energy of Methane," Applied Microbiology, vol. 7 (4), pp. 219-227, 1959.

[7] E. Uggetti, B. Sialve, E. Latrille, and J. P. Steyer, "Anaerobic digestate as substrate for microalgae culture: the role of ammonium concentration on the microalgae productivity," Bioresource technology, vol. 152, pp. 437-443, 2014. https://doi.org/10.1016/j.biortech.2013.11.036

[8] A. Richmond, Handbook of Microalgal Culture: Biotechnology and Applied Phycology, Blackwell Publishing, ISBN: 9780632059539, 2004.

[9] J. Cheng, J. Xu, Y. Huang, Y. Li, J. Zhou, and K. Cen, "Growth optimisation of microalga mutant at high $\mathrm{CO}_{2}$ concentration to purify undiluted anaerobic digestion effluent of swine manure," Bioresource technology, vol. 177, pp. 240-246, 2015.

[10] J. M. Juarez, E. R. Pastor, J. M. F. Sevilla, and R. M. Torre, "Effect of pretreatments on biogas production from microalgae biomass grown in pig manure treatment plants," Bioresource Technology, vol. 257 , pp. $30-38,2018$.

https://doi.org/10.1016/j.biortech.2018.02.063

[11]H. Wang, W. Zhang, L. Chen, J. Wang, and T. Liu, "The contamination and control of biological pollutants in mass cultivation of microalgae," Bioresource Technology, vol. 128, pp. 745-750, 2013. https://doi.org/10.1016/j.biortech.2012.10.158

[12]J. B. K. Park, R. J. Craggs, and A. N. Shilton, "Wastewater treatment high rate algal ponds for biofuel production," Bioresource Technology, vol. 102 (1), pp. 35-42, 2011. https://doi.org/10.1016/j.biortech.2010.06.158 